
8
Research Square
Preprints are preliminary reports that have not undergone peer review.
They should not be considered conclusive, used to inform clinical practice,
or referenced by the media as validated information

\title{
Meningitis caused by Mycobacterium fortuitum mimicking tuberculous meningitis in an immunocompetent patient: a case report and literature review.
}

\author{
Siran Lin \\ Huashan Hospital Fudan University Department of Infectious Diseases \\ Qingluan Yang \\ Huashan Hospital Fudan University Department of Infectious Diseases \\ Ting Wang \\ Jing'an District Centre Hospital of Shanghai \\ Wen Jia \\ Jing'an District Centre Hospital of Shanghai \\ Shu Chen \\ Huashan Hospital Fudan University Department of Infectious Diseases \\ Wenhong Zhang \\ Huashan Hospital Fudan University Department of Infectious Diseases \\ lingyun shao ( $\square$ lingyun26@fudan.edu.cn ) \\ Huashan Hospital Fudan University Department of Infectious Diseases
}

Case report

Keywords: Mycobacterium fortuitum, Meningitis, Nontuberculous mycobacteria (NTM), Case report

Posted Date: March 4th, 2020

DOI: https://doi.org/10.21203/rs.3.rs-15939/v1

License: (9) (7) This work is licensed under a Creative Commons Attribution 4.0 International License. Read Full License 


\section{Abstract}

Background: Nontuberculous mycobacteria (NTM) are a large group of microorganisms that mainly affect persons who have immune deficiency. Mycobacterium fortuitum is one of them, which usually cause soft tissue or pulmonary disease. Meningitis caused by $M$. fortuitum is extremely rare and is often confused with tuberculous meningitis (TBM) due to its low prevalence.

Case presentation: A 35-year-old woman was referred to our hospital with a history of headache, followed by fever, chills, cough, and vomiting. The results of mycobacterial culture and TSPOT. TB of her cerebrospinal fluid were positive. Therefore, she was diagnosed with tuberculous meningitis and was given antituberculous chemotherapy. During the observation, the CSF results were not significantly improved. Finally, hsp65 gene PCR revealed that the real pathogen was $M$. fortuitum. The treatment therapy was changed and the patient recovered after one-year combined chemotherapy.

Conclusions: In this case we described a patient with $M$. fortuitum meningitis who was immunocompetent with no trauma or surgical history. The wrong diagnosis with TBM was made due to positive results of both blood and CSF TSPOT. TB. The pathological evidence and microbiological analysis of hsp65 gene PCR suggested the real pathogen to be $M$. fortuitum. The diagnostic accuracy of blood and CSF TSPOT. TB in case of TBM is moderate. Infections of NTM cannot be excluded when the patient does not respond to anti-tuberculous therapy and it is of great significance to do molecular identification for clinical isolates of mycobacterium.

\section{Background}

In the past few decades, infections caused by non-tuberculous mycobacteria (NTM) have attracted considerable attention with its increasing prevalence [1-3]. NTM is widely distributed in the environment such as water and soil [4,5]. M. fortuitum is one of the rapidly growing mycobacteria (RGM), which usually causes skin and soft tissue infection as well as pulmonary diseases in some cases [6]. In the past, people who are susceptible to NTM infection were thought to be immunodeficient [7], such as patients with HIV/AIDS or people with deficiencies in the IFN- $\gamma$-IL-12 axis [8], while reports of infection in immunocompetent individuals are rare.

We herein describe an immunocompetent patient with meningitis caused by $\mathrm{M}$. fortuitum, which was to be confused with tuberculous meningitis. The correct diagnosis was made according to the results of hsp65 gene PCR, and the patient finally recovered after a long duration of combined chemotherapy.

\section{Case Presentation}

A 35-year-old woman had a continuous pulsatile headache, followed by fever, chills, cough, and vomiting. Her body temperature was $39.8^{\circ} \mathrm{C}$. At her local hospital, she was given cephalosporins for about a week. Her temperature returned to normal shortly afterwards until she got fever and headache again a few days later. She was re-admitted to her local hospital. Laboratory testing of her cerebrospinal fluid (CSF) revealed a glucose concentration of 2 mmol/L, a chlorine concentration of $118.0 \mathrm{mmol} / \mathrm{L}$, and a protein concentration of $835 \mathrm{mg} / \mathrm{L}$. During the hospitalization period, her symptoms got worsened, and she developed confusion and sleepiness. Blood tests showed a leucocyte count of $6.6 \times 10^{3}$ cells/ $\mu \mathrm{L}$, a neutrophil percentage of $89.8 \%$, and a C-reactive protein concentration of $3.19 \mathrm{mg} / \mathrm{L}$. All antinuclear antibody tests were negative. She was diagnosed with viral encephalitis. Acyclovir was administered as a singleagent antiviral therapy, together with mannitol for lowering the intracranial pressure (ICP). Despite these treatments, the patient showed no sign of improvement and was referred to our hospital on Day 20 since disease onset.

On admission, her ICP was $230 \mathrm{~mm} \mathrm{H}_{2} \mathrm{O}$. CSF test showed a leucocyte count of $127 \times 10^{6} / \mathrm{L}$ with $60 \%$ monocytes and $40 \%$ multinucleate cells, a glucose concentration of $1.60 \mathrm{mmol} / \mathrm{L}$, a chlorine concentration of $111.0 \mathrm{mmol} / \mathrm{L}$ and a protein concentration of $1427 \mathrm{mg} / \mathrm{L}$ (Table 1). Standard bacterial and fungal cultures of her CSF were negative. Cranial magnetic resonance imaging (MRI) suggested a clear enhancement of the meninges and abnormal signals in bilateral frontal lobes and the periventricular area, consistent with the imaging changes of meningoencephalitis caused by infection (Fig. 1a). The results of TSPOT.TB assay of her blood and CSF were both positive (Fig. 2). 
Table 1

The CSF findings and treatments during the disease course

\begin{tabular}{|c|c|c|c|c|c|c|}
\hline \multirow[t]{2}{*}{ Time } & \multicolumn{5}{|l|}{ CSF } & \multirow[t]{2}{*}{ Management } \\
\hline & $\begin{array}{l}\text { Pressure } \\
\left(\mathrm{mmH}_{2} \mathrm{O}\right)\end{array}$ & $\begin{array}{l}\text { White cell counts } \\
\left({ }^{*} 10^{\wedge} 6 / \mathrm{L}\right)\end{array}$ & Protein (mg/L) & Glucose (CSF/plasma, mmol/L) & $\mathrm{Cl}(\mathrm{mmol} / \mathrm{L})$ & \\
\hline 2015.12.22 & / & 170 & 835 & 2.0 & 118 & / \\
\hline 2015.12.29 & 230 & 127 & 1427 & $1.6 / 10.3$ & 111 & HRZE + LZD \\
\hline 2016.01.05 & 220 & 38 & 2073 & $1.1 / 5.6$ & 110 & HRZE + LZD \\
\hline 2016.01.12 & 110 & 36 & 2185 & $1.8 / 6.9$ & 113 & HRZE + LZD \\
\hline 2016.01.19 & 135 & 53 & 1815 & $1.3 / 7.0$ & 107 & HRZE + LZD \\
\hline 2016.01 .28 & 220 & 61 & 2523 & $1.8 / 6.5$ & 110 & HRZE + AMI \\
\hline 2016.02.16 & 40 & 26 & 2830 & $1.4 / 6.5$ & 104 & HRZE + LZD + AMI \\
\hline 2016.03.01 & 165 & 46 & 2889 & $2.3 / 6.7$ & 111 & HRZE + LZD + AMI \\
\hline 2016.03.21 & 40 & 13 & 1909 & $1.3 / 6.2$ & 115 & 3RZE + PAS + AMI \\
\hline 2016.03.31 & 130 & 42 & 1480 & $1.54 / 6.81$ & 117 & HRZE + LZD \\
\hline 2016.04.26 & 170 & 12 & 1068 & $1.7 / 5.16$ & 120 & HRZE + LZD \\
\hline 2016.05.26 & 90 & 2 & 901 & $2.7 / 7.22$ & 125 & $\begin{array}{l}\mathrm{AMI}+\mathrm{CFX}, \mathrm{LZD}+ \\
\mathrm{CLA}+\mathrm{DOX}+\mathrm{TMP} / \mathrm{SMX}\end{array}$ \\
\hline 2016.07.06 & 80 & 2 & 805 & $3.81 / 5.9$ & 121 & CLA + TMP/SMX \\
\hline NRR & $50-180$ & $0-8$ & $120-600$ & $2.5-4.5$ & $120-132$ & \\
\hline
\end{tabular}

Assuming tuberculous meningitis (TBM), the patient was given anti-tuberculosis therapy with a combination of drugs including isoniazid, rifampicin, pyrazinamide, ethambutol and linezolid. Her condition became stable gradually. She regained consciousness and her body temperature was reduced to normal range. Mycobacterial culture of her CSF turned out to be positive 15 days later, further confirming the diagnosis of TBM. After 6 weeks of combined anti-tuberculous chemotherapy, a re-examination of the patient's CSF showed a leucocyte count of $26 \times 10^{6} / \mathrm{L}$, with $54 \%$ monocytes and $46 \%$ multinucleate cells, a glucose concentration of $1.40 \mathrm{mmol} / \mathrm{L}$, a chlorine concentration of $104.0 \mathrm{mmol} / \mathrm{L}$ and a protein concentration of $2830 \mathrm{mg} / \mathrm{L}$ (Table 1 ). These results did not suggest an significant improvement, and her body temperature exhibited fluctuations between $37.5-38.8^{\circ} \mathrm{C}$.

Two months later, she experienced vomiting after breakfast, and a transient loss of consciousness ensued. Cranial Computed tomography (CT) showed multiple infarction in bilateral basal ganglia, consistent with changes of the brain in TBM patients. Further cranial MRI suggests acute cerebral infarction in the right basal ganglia, granulomas in bilateral temporal bases and suprasellar cistern and softening focus in left and bilateral temporal bases (Fig. 1b). Brain CT angiography (CTA) revealed stenosis and occlusion at the end of the left internal carotid artery, stenosis of the left anterior cerebral artery and fenestration of the right cerebral anterior artery.

Clopidogrel and dexamethasone were administered, along with the previous anti-tuberculosis regimens continued. After that, her consciousness was improved. However, her temperature was still higher than normal, and the results of CSF tests remained abnormal (Table 1). Since the curative effect of antituberculosis therapy was not satisfactory, we sought to reconsider the diagnosis. The mycobacterium cultured from the patient's CSF on the LöwensteinJensen medium was sent for molecular identification. Genomic DNA of the mycobacterial culture was extracted using the DNeasy blood and tissue kit (Qiagen, Inc., Valencia, CA), according to the manufacturer's instructions. The partial hsp 65 gene sequence of the isolate ( 373 bp) was $100 \%$ similar to that of M. fortuitum strains (Fig. 3). Accordingly, we discontinued the anti-tuberculosis medications and intravenously administered amikacin and cefoxitin for 1 week, followed by sequential oral administration of linezolid, clarithromycin, compound sulfamethoxazole and doxycycline combined. After the initiation of the new treatment plan, the patient's condition became stable. On 1.5-month follow-up, her CSF was significantly improved,with the cranial MRI suggesting a significant absorption of the previous lesion (Table 1, Fig. 1c). She was then discharged on oral maintenance therapy. The oral administration was continued for one year, after which the patient recovered with no symptoms of TBM, but some sequelae of cerebral infarction. A Gantt chart was used to summarize the the process of diagnosis and treatment of the patients (Fig. 4).

\section{Discussion And Conclusions}

Previous studies have shown that patients who developed $\mathrm{M}$. fortuitum meningitis were predominantly individuals with immunodeficiency, such as patients with HIV/AIDS[9-17] (Table 2). Patients who are normal immunocompetent usually have a history of trauma or surgery in the brain or spine[18], which enables M. fortuitum from the environment to enter into the central nervous system. However, in our case, we did not find predisposing factors as such in our patient, who was a normal immunocompetent woman without a trauma or surgical history. 
Table 2

Case reports of meningitis due to $\mathrm{M}$. fortuitum

\begin{tabular}{|c|c|c|c|c|c|c|c|c|c|}
\hline \multirow[t]{2}{*}{ Case } & \multicolumn{3}{|c|}{ Underlying condition } & \multirow{2}{*}{$\begin{array}{l}\text { Clinical } \\
\text { symptoms or } \\
\text { signs }\end{array}$} & \multirow[t]{2}{*}{ CSF tests } & \multirow{2}{*}{$\begin{array}{l}\text { CSF } \\
\text { stain }\end{array}$} & \multirow{2}{*}{$\begin{array}{l}\text { CSF } \\
\text { culture }\end{array}$} & \multirow{2}{*}{$\begin{array}{l}\text { Autopsy } \\
\text { findings }\end{array}$} & \multirow[t]{2}{*}{1} \\
\hline & Intervention & Immunodeficiency & $\begin{array}{l}\text { Trauma or } \\
\text { surgery(associated) }\end{array}$ & & & & & & \\
\hline $\begin{array}{l}\text { Santamaria- } \\
\text { Jauregui J } \\
\text { et al. } 1984 \\
\text { [9] }\end{array}$ & No & No & $\begin{array}{l}\text { Trauma in the } \\
\text { sacral region }\end{array}$ & $\begin{array}{l}\text { Fever, } \\
\text { headache, } \\
\text { vomiting, stiff } \\
\text { neck }\end{array}$ & $\begin{array}{l}\text { WBCs, } 1200 \\
\text { /ul (75\% } \\
\text { PMNs); } \\
\text { Protein, } \\
1.5 \mathrm{~g} / \mathrm{dl} ; \\
\text { Glucose, } \\
10 \mathrm{mg} / \mathrm{dl}\end{array}$ & Negative & $\begin{array}{l}\text { M. } \\
\text { fortuitum }\end{array}$ & $\begin{array}{l}\text { A foreign body } \\
\text { granuloma in } \\
\text { the wound }\end{array}$ & \{ \\
\hline $\begin{array}{l}\text { Smith M B } \\
\text { et al. } 1996 \\
\text { [10] }\end{array}$ & No & AIDs & No & $\begin{array}{l}\text { headache, } \\
\text { nausea, } \\
\text { vomiting, a stiff } \\
\text { neck }\end{array}$ & $\begin{array}{l}\text { WBCs, } 240 \\
\text { /ul (88\% } \\
\text { neutrophils); } \\
\text { Protein, } \\
0.70 \mathrm{~g} / \mathrm{L} ; \\
\text { Glucose, } \\
1.92 \mathrm{mmol} / \mathrm{L}\end{array}$ & Negative & Negative & $\begin{array}{l}\text { rare } \\
\text { multinucleated } \\
\text { giant cells but } \\
\text { no } \\
\text { granulomas } \\
\text { (brain) }\end{array}$ & $\begin{array}{l}\hat{s} \\
\mathrm{f} \\
\mathrm{c} \\
\mathrm{r} \\
\mathrm{f}\end{array}$ \\
\hline $\begin{array}{l}\text { Midani S et } \\
\text { al. } 1999 \text { [11] }\end{array}$ & VP shunt & No & No & $\begin{array}{l}\text { Fever, } \\
\text { headache, } \\
\text { tenderness } \\
\text { around the } \\
\text { shunt tract, } \\
\text { change in } \\
\text { mental status, } \\
\text { right-sided } \\
\text { weakness }\end{array}$ & $\begin{array}{l}\text { WBCs, } 335 \\
\text { /mm3 }(15 \% \\
\text { PMNs) }\end{array}$ & Negative & $\begin{array}{l}\text { M. } \\
\text { fortuitum }\end{array}$ & NA & $\begin{array}{l}t \\
1\end{array}$ \\
\hline $\begin{array}{l}\text { Madaras- } \\
\text { Kelly, K. J. } \\
1999 \text { [12] }\end{array}$ & $\begin{array}{l}\text { Epidural } \\
\text { catheter }\end{array}$ & No & No & $\begin{array}{l}\text { Headache, } \\
\text { nausea, emesis, } \\
\text { dizziness, } \\
\text { perception of } \\
\text { slowed } \\
\text { mentation, fever }\end{array}$ & $\begin{array}{l}\text { WBCs, } 562 \\
\text { /mm3 (59\% } \\
\text { PMNs); } \\
\text { Protein, } \\
274 \mathrm{mg} / \mathrm{dl} ; \\
\text { Glucose, } \\
16 \mathrm{mg} / \mathrm{dl}\end{array}$ & $1+\mathrm{GPB}$ & $\begin{array}{l}\text { M. } \\
\text { fortuitum }\end{array}$ & NA & c \\
\hline $\begin{array}{l}\text { Fujikawa, K. } \\
\text { et al. } 2006 \\
\text { [13] }\end{array}$ & No & No & $\begin{array}{l}\text { Surgery for } \\
\text { meningioma }\end{array}$ & NA & NA & Negative & $\begin{array}{l}\text { M. } \\
\text { fortuitum }\end{array}$ & NA & L \\
\hline $\begin{array}{l}\text { Kell, C. A. et } \\
\text { al. } 2008 \text { [14] }\end{array}$ & No & No & No & $\begin{array}{l}\text { Recurrent } \\
\text { double-vision, } \\
\text { paraesthesias, } \\
\text { vertigo; neck } \\
\text { stiffness, } \\
\text { singultus, } \\
\text { unsteady gait, a } \\
\text { palsy of the left } \\
\text { 6th and right } \\
\text { 4th cranial } \\
\text { nerve }\end{array}$ & $\begin{array}{l}\text { WBCs, } 100 \\
\text { /ul; Protein, } \\
2.5 \mathrm{~g} / \mathrm{l} ; \\
\text { Glucose, } \\
4 \mathrm{mmol} / \mathrm{l} ; \\
\mathrm{CSF} / \mathrm{serum} \\
\text { glucose } \\
\text { ratio: } 0.4\end{array}$ & $\begin{array}{l}\text { Very few } \\
\text { acid-fast } \\
\text { rods }\end{array}$ & Negative & $\begin{array}{l}\text { Caseating } \\
\text { granulomas } \\
\text { (brain) }\end{array}$ & $\begin{array}{l}\mathrm{E} \\
\mathrm{C} \\
\mathrm{E} \\
+ \\
1 \\
+\end{array}$ \\
\hline $\begin{array}{l}\text { Aliabadi, H. } \\
\text { et al. } 2008 \\
\text { [15] }\end{array}$ & $\begin{array}{l}\text { Intrathecal } \\
\text { catheter }\end{array}$ & No & No & $\begin{array}{l}\text { lowgrade } \\
\text { fevers, mild } \\
\text { erythema, } \\
\text { headache }\end{array}$ & $\begin{array}{l}2175 \\
\text { nucleated } \\
\text { cells, } 36 \\
\text { glucose, and } \\
116 \text { protein }\end{array}$ & NA & $\begin{array}{l}\text { M. } \\
\text { fortuitum }\end{array}$ & NA & $\begin{array}{l}1 \\
+1 \\
1\end{array}$ \\
\hline $\begin{array}{l}\text { Xess, A. B. } \\
\text { et al. } 2019 \\
\text { [16] }\end{array}$ & VP shunt & No & excision of glioma & $\begin{array}{l}\text { High-grade } \\
\text { fever, } \\
\text { altered } \\
\text { sensorium, } \\
\text { headache, } \\
\text { convulsions, } \\
\text { seizure }\end{array}$ & $\begin{array}{l}\text { Glucose: } \\
40 \mathrm{mg} / \mathrm{dL} ; \\
\text { Protein: } \\
50 \mathrm{mg} / \mathrm{dL} ; \\
\text { RBC: } 50 \\
\text { cells/mm3. }\end{array}$ & $\begin{array}{l}\text { Acid- } \\
\text { fast } \\
\text { bacilli } \\
\text { seen } \\
(3+)\end{array}$ & $\begin{array}{l}\text { M. } \\
\text { fortuitum }\end{array}$ & NA & $\begin{array}{l}\mathrm{L} \\
\mathrm{t} \\
\mathrm{C}\end{array}$ \\
\hline $\begin{array}{l}\text { Zakrzewski, } \\
\text { J et al. } 2019 \\
\text { [17] }\end{array}$ & LP shunt & No & No & NA & NA & NA & $\begin{array}{l}\text { M. } \\
\text { fortuitum }\end{array}$ & NA & $\uparrow$ \\
\hline
\end{tabular}

Abbreviations: VP ventriculoperitoneal, NA not available, LP lumboperitoneal, WBC white blood cell, INH isoniazid, SD sulfadiazine, TGC tetracycline, PEN pen PMNs polymorphonuclear leukocytes, GPB gram-positive bacilli, CAZ ceftazidime, VAN vancomycin, RFP rifampin, CIP ciprofloxacin, IMI imipenem, LVFX levc ethambutol, RFB rifabutin, MEM meropenem, OFX ofloxacin, CFZ clofazimine.

At onset, the patient presented with fever, headache, nausea and vomiting. According to previous studies, the common symptoms of TBM in adult patients were non-specific malaise, weight loss, low-grade fever, anorexia, and gradual onset of headache [19-21]. Subsequently, patients may develop more severe 
headache, vomiting, altered mental status, or stroke, leading to coma and death if left untreated [20]. Body signs of clinical significance include neck stiffness of variable degrees, cranial nerve palsies which develop as disease progresses along with confusion and coma deepening [19].

Examination of the CSF is essential for the diagnosis and management of TBM. Characteristic CSF findings of TBM include higher ICP ( $>25 \mathrm{~cm} \mathrm{H} 20$ ), raised white blood cell counts $\left(0.05 \times 10^{9}-1.00 \times 10^{9} / \mathrm{L}\right.$; mostly lymphocytes), raised protein $(0.5-2.5 \mathrm{~g} / \mathrm{L})$ and low glucose with CSF/plasma ratio $<0.5$ [19-21]. Basal meningeal exudates, infarcts, tuberculomas and hydrocephalus are all common features of TBM. Our patient had both basal meningeal enhancement and infarcts.

Confirmation of the diagnosis of TBM can be difficult. Often, the diagnosis is made with a delay of several weeks or months due to non-specific symptoms. The Vietnam diagnostic rule for the diagnosis of TBM in adults focuses on age, white blood cell counts, history of illness and CSF findings [22]. A number of studies up to date have evaluated the diagnostic value of blood and CSF T-SPOT.TB assays on TBM. A meta-analysis published in 2016 revealed the overall sensitivities for blood and CSF interferon gamma release assay (IGRA) were respectively 0.78 and 0.77 , and the specificities were 0.61 and 0.88 [23]. In a prospective study by Kim et al, which included 276 patients, the reported sensitivity and specificity of the PBMC ELISPOT assay for diagnosing TBM from nonTBM were respectively $96 \%$ and $58 \%$. The ELISPOT assay of CSF has a sensitivity of $68 \%$ and a specificity of $95 \%$ [24]. Indeed, the diagnostic specificity of blood and CSF T-SPOT.TB for TBM is relatively high. Therefore in our case, given positive results of both the mycobacterial culture and the T-SPOT.TB of CSF, we falsely assumed that the diagnosis was TBM and prescribed empirical anti-tuberculosis treatment to our patient. The CSF laboratory tests were reviewed several times after the initiation of anti-tuberculosis treatment and showed no significant improvement, which leads to our reevaluation of the diagnosis of TBM.

M. fortuitum is generally sensitive to multiple oral antimicrobial agents, such as sulfonamides, fluoroquinolones, minocycline, and doxycycline [25]. The ATS/IDSA guidelines recommend treatment of pulmonary disease caused by NTMs with at least two active agents for 12 months of culture negativity. However, there are currently no guidelines for meningitis caused by NTM, and high-level clinical evidence from randomized controlled trials or prospective cohort studies is lacking [26]. Upon the confirmation of M.fortuitum infection, we changed the regimens as described above. After one year of chemotherapy, the patient finally recovered with only a few sequelae caused by cerebral infarctions.

\section{Abbreviations}

NTM: Non-tuberculous mycobacteria; RGM: Rapidly growing mycobacteria; CSF: Cerebrospinal fluid; ICP: Intracranial pressure; MRI: Magnetic resonance imaging; TBM: Tuberculous meningitis; CT: Computed tomography; CTA: Computed tomography angiography; IGRA: Interferon gamma release assay

\section{Declarations}

Ethics approval and consent to participate

Not applicable.

Consent for publication

Written informed consent was obtained from the patient for publication of this case report and all accompanying images.

Availability of data and materials

All the data supporting our findings is contained within the manuscript.

Competing interests

The authors declare that they have no competing interests

Funding

Not applicable.

Authors' contributions

SRL performed literature search and wrote the manuscript. QLY, TW and WJ collected and analyzed data of this patient. WHZ, LYS and SC participated in the treatment of

the patient during hospitalization. All authors have read and approved the final manuscript.

Acknowledgements

Not applicable.

\section{References}

[1]. Ringshausen, F.C., et al., Prevalence of Nontuberculous Mycobacterial Pulmonary Disease, Germany, 2009-2014. Emerg Infect Dis, 2016. 22(6): p. 1102-5.

Page 5/9 
[2]. Namkoong, H., et al., Epidemiology of Pulmonary Nontuberculous Mycobacterial Disease, Japan. Emerg Infect Dis, 2016. 22(6): p. 1116-7.

[3]. Koh, W.J., Nontuberculous Mycobacteria-Overview. Microbiol Spectr, 2017. 5(1).

[4]. Goslee, S. and E. Wolinsky, Water as a source of potentially pathogenic mycobacteria. Am Rev Respir Dis, 1976. 113(3): p. $287-92$.

[5]. Wolinsky, E. and T.K. Rynearson, Mycobacteria in soil and their relation to disease-associated strains. Am Rev Respir Dis, 1968. 97(6): p. 1032-7.

[6]. Brown-Elliott, B.A. and R.J. Wallace, Clinical and taxonomic status of pathogenic nonpigmented or late-pigmenting rapidly growing mycobacteria. Clin Microbiol Rev, 2002. 15(4): p. 716-46.

[7]. Henkle, E. and K.L. Winthrop, Nontuberculous mycobacteria infections in immunosuppressed hosts. Clin Chest Med, 2015. 36(1): p. 91-9.

[8]. Wu, U.I. and S.M. Holland, Host susceptibility to non-tuberculous mycobacterial infections. Lancet Infect Dis, 2015. 15(8): p. 968-80.

[9]. Santamaria-Jauregui, J., et al., Meningitis caused by Mycobacterium fortuitum. Am Rev Respir Dis, 1984. 130(1): p. 136-7.

[10]. Smith, M.B., M.C. Boyars and G.L. Woods, Fatal Mycobacterium fortuitum meningitis in a patient with AIDS. Clin Infect Dis, 1996. 23(6): p. 1327-8.

[11]. Midani, S. and M.H. Rathore, Mycobacterium fortuitum infection of ventriculoperitoneal shunt. South Med J, 1999. 92(7): p. 705-7.

[12]. Madaras-Kelly, K.J., T.A. DeMasters and D.L. Stevens, Mycobacterium fortuitum meningitis associated with an epidural catheter: case report and a review of the literature. Pharmacotherapy, 1999. 19(5): p. 661-6.

[13]. Fujikawa, K., et al., [A case of Mycobacterium fortuitum meningitis following surgery for meningioma]. Rinsho Shinkeigaku, 2006. 46(7): p. 480-4.

[14]. Kell, C.A., et al., Chronic meningoencephalomyelitis due to Mycobacterium fortuitum in an immunocompetent patient. J Neurol, 2008. 255(11): p. 1847-9.

[15]. Aliabadi, H. and R.K. Osenbach, Intrathecal Drug Delivery Device Infection and Meningitis due to Mycobacterium Fortuitum: A Case Report. Neuromodulation, 2008. 11(4): p. 311-4.

[16]. Xess, A.B., et al., Mycobacterium fortuitum as a cause of acute CNS infection in an immune-competent girl undergoing repeated VP shunt surgeries. BMJ Case Rep, 2019. 12(4).

[17]. Zakrzewski, J., et al., Mycobacterium fortuitum Meningitis: Approach to Lumboperitoneal Shunt Infection. South Med J, 2019. 112(4): p. 217-221.

[18]. Nontuberculous mycobacterial meningitis report of two cases and review.

[19]. Thwaites, G.E., R. van Toorn and J. Schoeman, Tuberculous meningitis: more questions, still too few answers. Lancet Neurol, 2013. 12(10): p. 9991010.

[20]. Marx, G.E. and E.D. Chan, Tuberculous Meningitis: Diagnosis and Treatment Overview. Tuberculosis Research and Treatment, 2011. 2011: p. 1-9.

[21]. Torok, M.E., Tuberculous meningitis: advances in diagnosis and treatment. British Medical Bulletin, 2015. 113(1): p. $117-131$.

[22]. Thwaites, G.E., et al., Diagnosis of adult tuberculous meningitis by use of clinical and laboratory features. Lancet, 2002. 360(9342): p. 1287-92.

[23]. Yu, J., et al., Diagnostic accuracy of interferon-gamma release assays for tuberculous meningitis: a meta-analysis. The International Journal of Tuberculosis and Lung Disease, 2016. 20(4): p. 494-499.

[24]. Park, K., et al., Diagnostic usefulness of T-cell based assays for tuberculous meningitis in HIV-uninfected patients. Journal of Infection, 2016. 72(4): p. 486-497.

[25]. Kasperbauer, S.H. and M.A. De Groote, The Treatment of Rapidly Growing Mycobacterial Infections. Clinics in Chest Medicine, 2015. 36(1): p. 67-78.

[26]. Griffith, D.E., et al., An Official ATS/IDSA Statement: Diagnosis, Treatment, and Prevention of Nontuberculous Mycobacterial Diseases. American Journal of Respiratory and Critical Care Medicine, 2007. 175(4): p. 367-416.

\section{Figures}



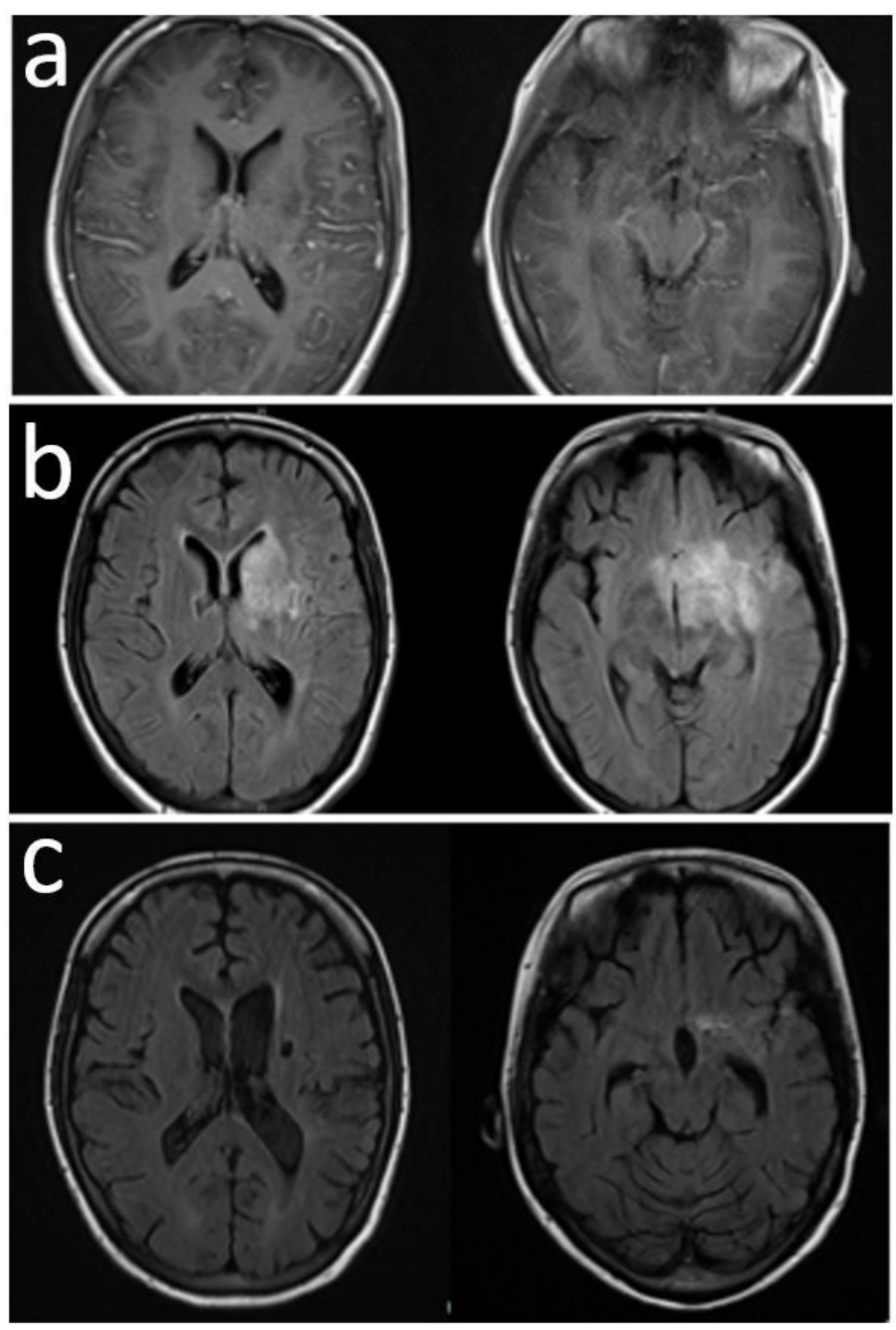

\section{Figure 1}

Cranial MRI performed during the disease course. a At the time when the patient was admitted. The meninges was significantly enhanced. Abnormal signals appeared in the bilateral frontal lobes and the periventricular area. b At one month after anti-tuberculosis therapy. The intracranial lesions were progressing, and there were large enhanced lesions in the basal ganglia and the skull base. c At one and half months after several regimen for rapid nontuberculous mycobacterium was administered. Most lesions in the basal ganglia and ambient cistern were absorbed.

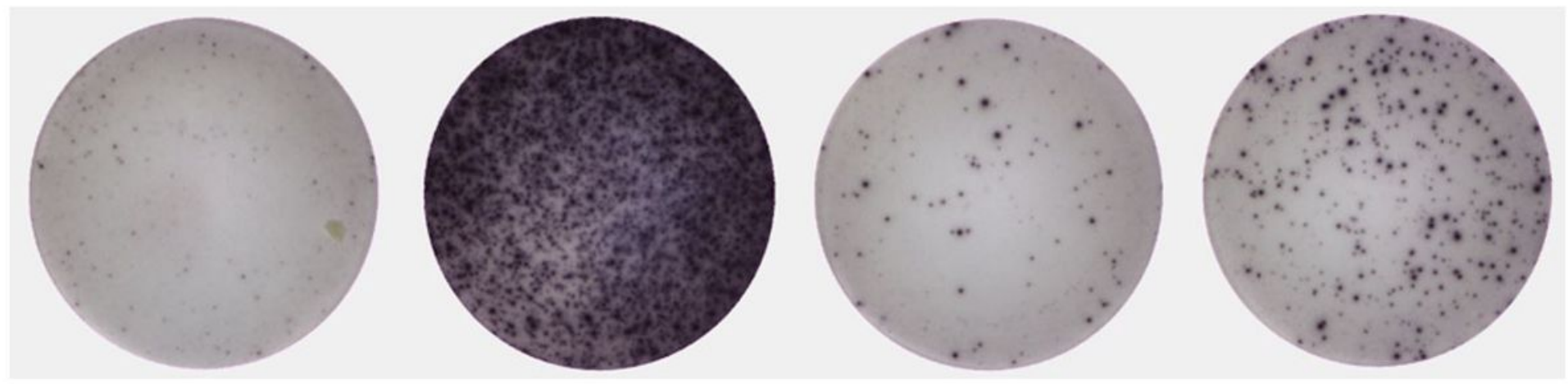

Figure 2

The results of T-SPOT.TB of CSF. From left to right: Nil Control, Positive Control, Panel A (ESAT-6), Panel B (CFP-10). The number of spots in panel A - nil and in panel B - nil were both $>8$. According to the supplier's instructions, the result was positive. 
Color key for alignment scores

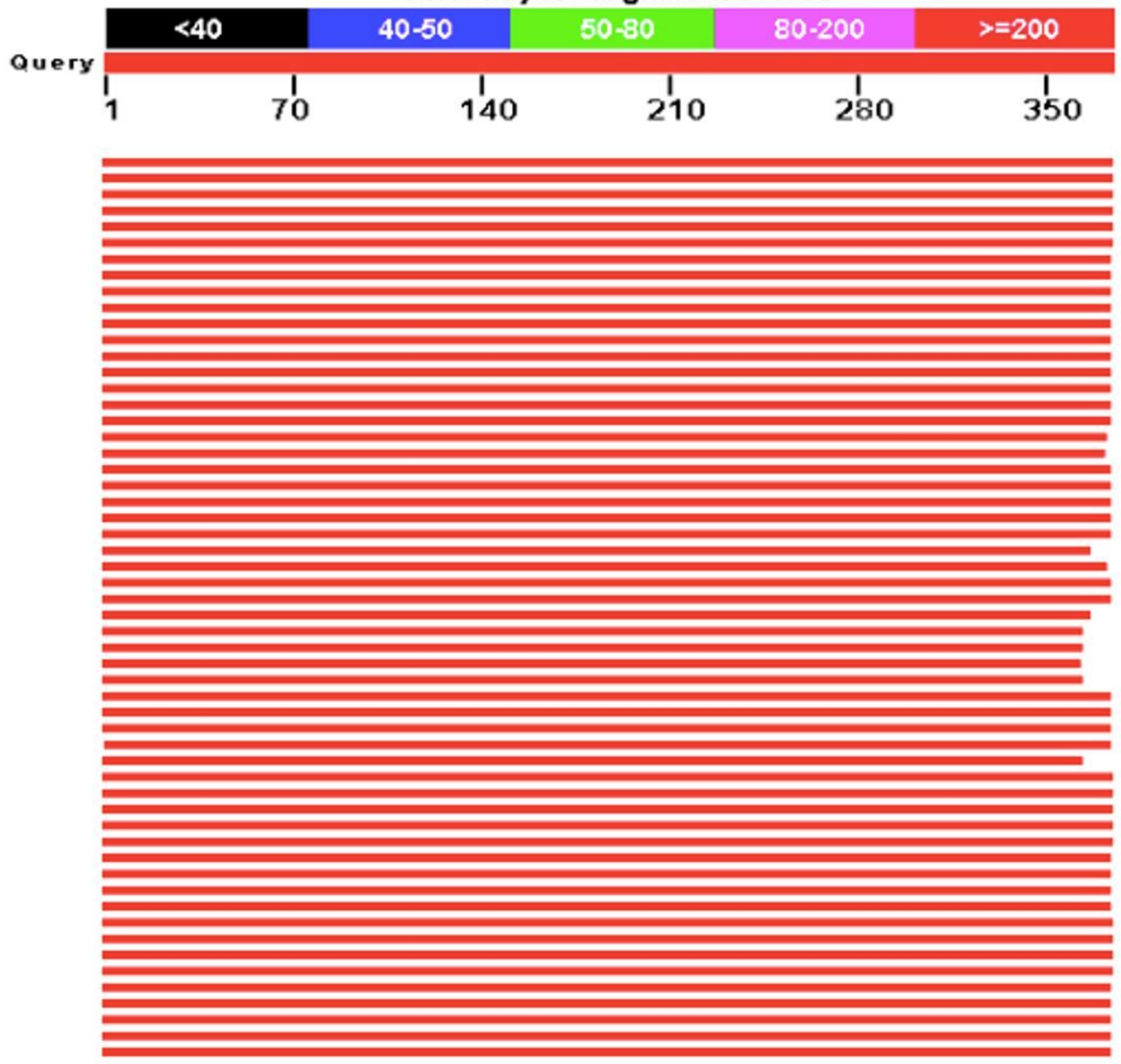

Figure 3

The alignment result of the hsp65 gene by online tool BLAST.

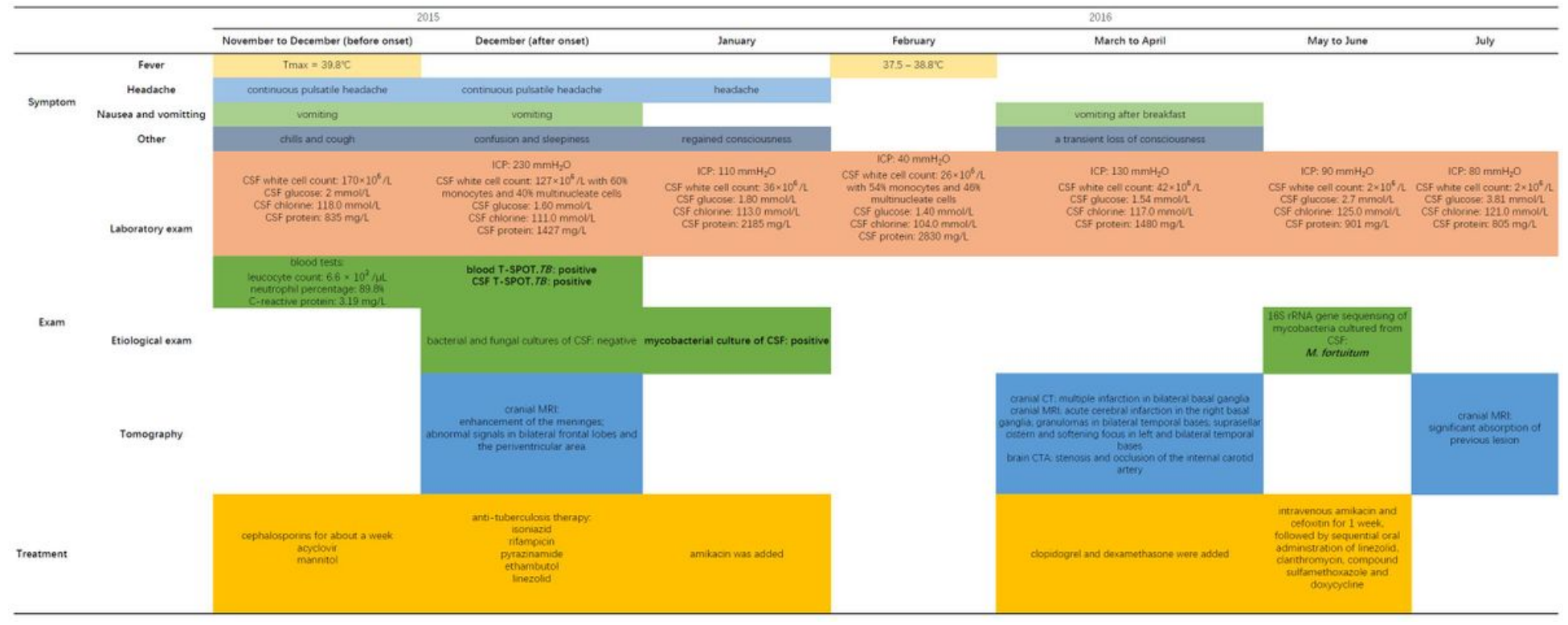

\section{Figure 4}

The Gantt chart that illustrates the course of the patient's disease.

\section{Supplementary Files}


This is a list of supplementary files associated with this preprint. Click to download.

- CAREchecklist.docx

Page 9/9 